\title{
Helicobacter Pylori: a comprehensive review for primary care providers
}

\author{
ALFRED NELSON $^{1}$, YAN BI ${ }^{1}$, DANA HARRIS ${ }^{2}$ \\ ${ }^{1}$ Division of Gastroenterology and Hepatology, Mayo Clinic, Jacksonville, FL, USA \\ ${ }^{2}$ Department of Community Internal Medicine, Mayo Clinic, Jacksonville, FL, USA
}

\begin{abstract}
Helicobacter pylori is the most prevalent bacteria infecting humans resulting in a variety of gastrointestinal and extra gastrointestinal complications. Although most of the infected adults are asymptomatic, the prevalence varies in different parts of the world it is higher in Eastern and Southern Europe. Eradication of Helicobacter pylori is necessary to prevent precancerous conditions like gastric atrophy, gastric intestinal metaplasia and gastric dysplasia. This comprehensive review addresses briefly on: whom and how to test and treat including recommended first line therapies, salvage therapies, testing for eradication and strategy to be used in primary care clinics.
\end{abstract}

Key words: eradication, atrophy, metaplasia, dysplasia and salvage.

\author{
Abbreviations: \\ $\mathrm{HP}=$ Helicobacter pylori \\ PUD $=$ Peptic Ulcer Disease \\ MALT = Low-grade gastric marginal zone B-cell lymphoma \\ UBT $=$ Urea Breath Test \\ $\mathrm{RCT}=$ Randomized Controlled Trial
}

\section{INTRODUCTION}

Helicobacter pylori (HP) is a Gram-negative microaerophilic bacteria which was discovered more than 3 decades ago by pathologist Robin Warren who first reported curved bacteria colonizing the gastric mucosa and suggested the possibility of causing gastric inflammation [1]. With an estimated 4.4 billion infected individuals, the prevalence of HP varies in different parts of the world, highest in developing countries in Africa $(79.1 \%)$, Latin America and the Caribbean (63.4\%), and Asia (54.7\%). In the USA and Western European countries the prevalence is decreasing [2] but varies by race, highest in Alaskan Natives $75.0 \%$ [3], followed by non-whites $(34.5 \%$ to $61.6 \%)$ $[4,5]$ and whites $(18.4 \%$ to $26.2 \%)$. In Europe, prevalence is higher in Eastern (62.8\%) and Southern Europe $(55.0 \%)$ and lower in Northern $(41.6 \%)$ and Western Europe (34.3\%). The country with the highest prevalence is Portugal $86.4 \%$. In Eastern Europe, the prevalence is highest in Russia (78.5\%). Romania has a prevalence of $68.5 \%$, and the Czech Republic has the lowest prevalence (41.2\%) [2].
The exact means of acquisition of the infection is not always clear, but the most common risk factors are low socioeconomic status, infected parents, the number of siblings and community water supplies in some developing countries [6-8]. H. Pylori has been associated with numerous gastrointestinal complications like chronic gastritis, gastric ulcer, duodenal ulcer, chronic uninvestigated dyspepsia, functional dyspepsia, gastric cancer, and low-grade gastric marginal zone B-cell lymphoma (formerly known as gastric mucosa-associated lymphoid tissue B-cell lymphoma) [9]. Other extra-gastric complications, less common and with less evidence of association, include hematological disorders (iron deficiency anemia, Vitamin B12 deficiency, immune thrombocytopenic purpura, ischemic heart disease and neurodegenerative diseases [10-11]. HP was declared a class I human carcinogen by the International Agency for Research on Cancer [12]. Eradication therapy of HP before the onset of precancerous lesions (gastric atrophy, gastric intestinal metaplasia, and gastric dysplasia) had significantly decreased the risk of developing gastric cancer [13]. Since most of the HP infections in adults are 
asymptomatic, the eradication for HP is offered to symptomatic individuals and those at risk for developing complications from HP infection. [14].

This is a practical and comprehensive guide to be used in primary care clinics for screening, testing and treating HP.

\section{Whom to test}

1. All patients with active gastric and duodenal peptic ulcer disease (PUD) [14], previous history of PUD (not treated or no documented cure), low-grade gastric marginal zone B-cell lymphoma [15], a history of early gastric cancer or gastrointestinal metaplasia resection [16, dyspepsia under the age of 60 years with no alarm features \{Ford, 2008 \#17], long term low dose aspirin, chronic treatment with a nonsteroidal anti-inflammatory drug (NSAID), unexplained iron deficiency anemia after extensive evaluation, and adults with idiopathic thrombocytopenic purpura (ITP)[14].

2. If endoscopy is obtained in dyspepsia, obtain biopsies for HP testing [14].

3. Do not test patients with typical symptoms of gastroesophageal reflux disease (GERD) without a history of PUD [17].
4. There is inadequate evidence to test and treat HP in asymptomatic individuals with a family history of gastric cancer, hyperplastic gastric polyps and hyperemesis gravidarum [14].

\section{How to test}

The diagnosis of HP can be broadly classified into non-invasive and invasive methods. Non-invasive methods are preferred since they are easier to obtain, with less risk of harm and at a lower cost than endoscopy-based invasive methods (Table 1).

${ }^{13} \mathrm{C}$ or radioactive ${ }^{14} \mathrm{C}$-urea breath test (UBT), stool antigen test, and serum antibody testing are the most common non-invasive methods. ${ }^{13} \mathrm{C}$-UBT has a high sensitivity (88\%-95\%) and specificity $(95 \%-100 \%)$ [18]. The basis of UBT is hydrolysis of urea with a carbon isotope being converted by HP to produce $\mathrm{CO}^{2}$ and ammonia $[19,20]$. Stool antigen testing using laboratory-based monoclonal enzyme immunoassay has high sensitivity and specificity (94 and 97\% respectively) [21, 22]. ELISA based serological testing to detect $\operatorname{IgG}$ antibodies is inexpensive but fails to distinguish between active and past infection [23, 24].

Table 1

Methods of testing for HP

\begin{tabular}{|c|c|c|c|c|}
\hline Testing & Method & Pros & Cons & Comments \\
\hline \multirow{3}{*}{$\begin{array}{l}\text { Non- } \\
\text { invasive }\end{array}$} & $\begin{array}{l}\text { Urea breath } \\
\text { testing (UBT) }\end{array}$ & \begin{tabular}{|l|} 
Simple and safe \\
Easy to perform \\
High sensitivity and specificity \\
High diagnostic accuracy \\
\end{tabular} & $\begin{array}{l}\text { False positive results due to urease } \\
\text { producing organisms; } \\
\text { Radiation if }{ }^{14} \mathrm{C} \text { is used }\end{array}$ & $\begin{array}{l}\text { Most commonly used False- } \\
\text { negative results with PPIs or } \\
\text { antibiotics use or in active UGIB } \\
\text { (low specificity). }\end{array}$ \\
\hline & $\begin{array}{l}\text { Stool antigen } \\
\text { testing }\end{array}$ & $\begin{array}{l}\text { High sensitivity and specificity } \\
\text { No special skill required }\end{array}$ & Sample collection & $\begin{array}{l}\text { Most commonly used False- } \\
\text { positive results with PPIs or } \\
\text { antibiotics use } \\
\text { High sensitivity after UGIB. }\end{array}$ \\
\hline & Serology & $\begin{array}{l}\text { Simple blood test } \\
\text { Not affected by UGIB }\end{array}$ & $\begin{array}{l}\text { Cannot distinguish past or active } \\
\text { infection }\end{array}$ & $\begin{array}{l}\text { Rarely used but a negative test } \\
\text { has high negative predictive } \\
\text { value during active UGIB. } \\
\text { No false negatives with PPI use. }\end{array}$ \\
\hline \multirow{4}{*}{ Invasive } & $\begin{array}{l}\text { Rapid biopsy } \\
\text { urease testing }\end{array}$ & $\begin{array}{l}\text { Rapid and cheap } \\
\text { High specificity (99\%) }\end{array}$ & Low sensitivity ( $80 \%)$ & $\begin{array}{l}\text { Most commonly used } \\
\text { False-negative results with PPIs } \\
\text { or antibiotics use. } \\
\text { Low sensitivity with UGIB* }\end{array}$ \\
\hline & Histology & $\begin{array}{l}\text { Gold standard } \\
\text { Cheap and universally used }\end{array}$ & $\begin{array}{l}\text { Florescent microscopy use for } \\
\text { detection } \\
\text { Might require addition biopsy } \\
\text { sample }\end{array}$ & Most commonly used. \\
\hline & Culture & $\begin{array}{l}\text { Data about antibiotic resistance } \\
\text { is obtained } \\
\text { High specificity }\end{array}$ & $\begin{array}{l}\text { Time consuming } \\
\text { Ideal incubation conditions/ } \\
\text { transport medium needed } \\
\text { Low sensitivity }\end{array}$ & $\begin{array}{l}\text { False-negative results with PPIs } \\
\text { or antibiotics use. } \\
\text { NOT commonly used. }\end{array}$ \\
\hline & PCR & $\begin{array}{l}\text { Data about antibiotic resistance } \\
\text { is obtained } \\
\text { Rapid test } \\
\text { High specificity } \\
\text { Used in low bacterial load }\end{array}$ & $\begin{array}{l}\text { Low sensitivity } \\
\text { Higher cost } \\
\text { Time consuming process } \\
\text { Risk }\end{array}$ & NOT commonly used. \\
\hline
\end{tabular}


When endoscopy is indicated (dyspepsia with alarm symptoms, gastrointestinal bleeding, concerns for malignancy), HP can be detected with any of the following methods: biopsy for rapid urease test (BRUT), histology, polymerase chain reaction and less commonly by bacterial culture [25]. BRUT is cheap, fast and highly specific test but sensitivity is affected by the number of bacteria in the biopsy and other urease producing bacteria which lead to false positive test results [26]. The sensitivity and specificity of histological diagnosis of HP depends on colonization in the mucosa, location of the biopsy and pathologist expertise with special stains [27, 28]. PCR testing is used to detect low bacterial loads and specific type of mutations with antimicrobial resistance [29]. Culture is cumbersome but has the highest specificity with variable sensitivity due to quality of biopsies, transport conditions and very slow growth of HP [30].

\section{Whom to treat}

Everyone with a positive HP test should be offered treatment [14].

\section{How to treat}

Selection of the treatment regimen is based on a combination of factors:

1) Allergy to penicillin

2) Local resistance to clarithromycin

3) History of macrolide use

4) History of quinolone use

Treatment regimens include PPI twice daily and a combination of antibiotics (2 antibiotics in triple therapy or 3 antibiotics in quadruple therapy) for 10 to 14 days. These regimens are recommended by specialty groups (American College of Gastroenterology, Toronto Consensus and Maastricht V/Florence Consensus) (Tables 2 and 3).

Treatment efficacy is decreased with decreased compliance, high gastric acidity, high bacterial load and especially sensitivity of bacteria to antibiotics, most importantly to clarithromycin [24]. Nitroimidazole (metronidazole or tinidazole) resistance is less important and 14-day treatment regimen seems to overcome this resistance [24].

It is imperative to know the resistance of clarithromycin or local eradication rate with clarithromycin triple therapy regimen before choosing it as a first line regimen.

\section{Recommended first line therapies:}

1) PAC, PMC Clarithromycin triple therapy (PPI, amoxicillin or metronidazole plus clarithromycin) is recommended in areas where clarithromycin resistance is $<15 \%$. Higher eradication rates are achieved with 14 days [31].

2) PBMT Bismuth quadruple therapy (PPI, bismuth, metronidazole, tetracycline) is the preferred therapy in areas of high resistance to clarithromycin and metronidazole, and in patients who were previously treated with macrolides [14, 23, 33]. Ten to 14 days of this therapy is superior to 7 days of clarithromycin triple therapy ( $85 \%$ vs $73 \%$ ). If bismuth is not available, consider regimens with rifampin, levofloxacin or high dose amoxicillin [24].

3) PAMC Concomitant therapy (PAMC-PPI, amoxicillin, metronidazole, clarithromycin) is recommended in areas of only clarithromycin resistance and in patients without prior macrolide use [24]. The cure rates are $90 \%$ with concomitant therapy compared to $78 \%$ with clarithromycin triple therapy [34]. The duration of proven efficacy of this treatment is 10 days and the consensus group recommendation is for 14 days [14].

4) Probiotics: There is increasing evidence to the benefit of probiotics as adjuncts to antibiotics and PPI [14]. Lactobacillus reuteri when supplemented with the triple therapy reduced side effects of treatment, increased eradication rate and improved the histological features of $H$. pylori infection when compared to placebo [32].

\section{Salvage therapies:}

Levofloxacin is recommended as first line treatment only by American College of Gastroenterology (ACG) and not by the other consensus groups due to concerns for increasing levofloxacin resistance and decreased efficacy [14, $23,33]$. Sequential and hybrid therapies are given for 5-7 days followed by another 5-7 days with a different antibiotic combination.

1) PAL Levofloxacin triple therapy (PPI, levofloxacin, amoxicillin) has a pooled eradication rate of $84 \%$ (range $73-92 \%$ ) with 10-day therapy [35-37]. After 2 failed other treatments (clarithromycin triple therapy and bismuth quadruple therapy), the pooled eradication rate with levofloxacin-based therapy is $73 \%$ (188). Fourteen days is more effective and has higher efficacy in eradication of HP [38].

2) Levofloxacin sequential therapy consisting of first 5-7 days of PPI and amoxicillin followed by 5-7 days of a PPI, levofloxacin, and nitroimidazole. It has superior eradication compared to clarithromycin triple therapy ( $83.6 \%$ vs. $64 \%$ ) or standard sequential therapy $(87.4 \%$ vs. $78.9 \%)$ with clinical significance [39]. 
3) LOAD (PPI, levofloxacin, doxycycline, nitazoxanide) 10-day therapy provides an eradication rate of $90 \%$ compared to $73 \%$ of clarithromycin triple therapy [14].

4) Sequential therapy (PPI and amoxicillin for 5 days followed by PPI, clarithromycin, metronidazole for an additional 5 days) has an overall eradication rate of $84.3 \%$. The efficacy of this regimen varies geographically, with higher eradications rates seen in Italy when compared to United States and Latin American countries [34, 40] (Table 2). This regimen is not superior to 14 days of clarithromycin triple therapy [20].
5) HDDT High dose dual regimen (PPI, amoxicillin high dose) has an eradication rate of $71 \%$ and there is no significant difference when compared to rifabutin triple therapy [41]. The efficacy is due to a combination of factors: HP does not develop resistance to amoxicillin and efficacy of amoxicillin is increased with elevated $\mathrm{pH}[42,43]$.

6) PAR Rifabutin triple therapy (PPI, amoxicillin, rifabutin) is recommended as salvage therapy due to concern for myelosuppression and drug interactions with prolonged use. A 10-day regimen has an eradication of $87 \%$ [44].

Table 2

Treatment regimens for HP recommended by the consensus groups (ACG, Toronto and Maastricht V/Florence)

\begin{tabular}{|c|c|c|c|}
\hline Drug Regimen & Dosing & $\begin{array}{l}\text { Duration } \\
\text { (days) }\end{array}$ & Recommendation \\
\hline $\begin{array}{l}\text { Bismuth } \\
\text { quadruple } \\
\text { (PBMT) }\end{array}$ & $\begin{array}{l}\text { PPI bid } \\
\text { Bismuth qid } \\
* \text { Metronidazole } 400 \mathrm{mg} \text { qid or } 500 \mathrm{mg} \text { tid-qid } \\
\text { Tetracycline } 500 \mathrm{mg} \text { qid }\end{array}$ & 14 & $\begin{array}{l}\text { First line } \\
\text { Areas of high resistance to both } \\
\text { clarithromycin and metronidazole } \\
\text { Salvage therapy if not tried before. }\end{array}$ \\
\hline $\begin{array}{l}\text { Concomitant non- } \\
\text { bismuth } \\
\text { quadruple } \\
\text { (PAMC) }\end{array}$ & $\begin{array}{l}\text { PPI bid } \\
\text { Amoxicillin } 1000 \mathrm{mg} \text { bid } \\
* \text { Metronidazole } 500 \mathrm{mg} \text { bid } \\
\text { Clarithromycin } 500 \mathrm{mg} \text { bid }\end{array}$ & 14 & $\begin{array}{l}\text { First line } \\
\text { Areas of high resistance to only } \\
\text { clarithromycin } \\
\text { Salvage therapy if not tried before. }\end{array}$ \\
\hline $\begin{array}{l}\text { Clarithromycin } \\
\text { triple (PAC, } \\
\text { PMC) }\end{array}$ & $\begin{array}{l}\text { PPI bid } \\
\text { Amoxicillin } 1000 \mathrm{mg} \text { or metronidazole } 500 \mathrm{mg} \\
\text { bid } \\
\text { Clarithromycin } 500 \mathrm{mg} \text { bid }\end{array}$ & 14 & $\begin{array}{l}\text { First line } \\
\text { Use only if the clarithromycin } \\
\text { resistance is }<15 \%\end{array}$ \\
\hline $\begin{array}{l}\text { Levofloxacin } \\
\text { triple } \\
\text { (PAL) }\end{array}$ & $\begin{array}{l}\text { PPI bid } \\
\text { Amoxicillin } 1000 \mathrm{mg} \text { bid } \\
\text { Levofloxacin } 500 \mathrm{mg} \text { once daily or } 250 \mathrm{mg} \text { bid }\end{array}$ & 14 & Salvage \\
\hline $\begin{array}{l}\text { Levofloxacin } \\
\text { Sequential }\end{array}$ & $\begin{array}{l}\text { PPI bid } \\
\text { Amoxicillin } 1000 \mathrm{mg} \text { bid for } 5-7 \text { days } \\
\text { PPI bid, Amoxicillin } 1000 \mathrm{mg} \text { bid, } \\
\text { Levofloxacin } 500 \mathrm{mg} \text { once daily, metronidazole } \\
500 \mathrm{mg} \text { bid for } 5-7 \text { days }\end{array}$ & $10-14$ & Salvage \\
\hline LOAD & $\begin{array}{l}\text { PPI bid } \\
\text { Doxycycline } 100 \mathrm{mg} \text { daily } \\
\text { Levofloxacin } 500 \mathrm{mg} \text { once daily } \\
\text { Nitazoxanide } 500 \mathrm{mg} \text { Bid }\end{array}$ & $7-10$ & Salvage \\
\hline $\begin{array}{l}\text { Sequential non- } \\
\text { bismuth } \\
\text { Quadruple } \\
\text { (Sequential) }\end{array}$ & $\begin{array}{l}\text { PPI bid } \\
\text { Amoxicillin } 1000 \mathrm{mg} \text { bid for } 5-7 \text { days followed } \\
\text { by } \\
\text { *Metronidazole } 500 \mathrm{mg}+\text { clarithromycin } \\
500 \mathrm{mg} \text { bid for } 5-7 \text { days more }\end{array}$ & $10-14$ & $\begin{array}{l}\text { Salvage } \\
\text { Do not use in areas of clarithromycin } \\
\text { resistance is high } \\
\text { Rarely used }\end{array}$ \\
\hline $\begin{array}{l}\text { Hybrid non- } \\
\text { bismuth } \\
\text { Quadruple } \\
\text { (Hybrid) }\end{array}$ & $\begin{array}{l}\text { PPI bid } \\
\text { Amoxicillin } 1000 \mathrm{mg} \text { bid } \\
\text { *Metronidazole } 500 \mathrm{mg} \text { for } 7 \text { days }+ \\
\text { clarithromycin } \\
500 \mathrm{mg} \text { bid for } 7 \text { days }\end{array}$ & 14 & $\begin{array}{l}\text { Salvage } \\
\text { Rarely used }\end{array}$ \\
\hline $\begin{array}{l}\text { High-dose dual } \\
\text { therapy (HDDT) }\end{array}$ & $\begin{array}{l}\text { Rabeprazole } 20 \mathrm{mg} \text { qid } \\
\text { Amoxicillin } 750 \mathrm{mg} \text { qid }\end{array}$ & 14 & Salvage \\
\hline $\begin{array}{l}\text { Rifabutin- } \\
\text { containing } \\
\text { therapy (PAR) }\end{array}$ & $\begin{array}{l}\text { PPI bid } \\
\text { Amoxicillin } 1000 \mathrm{mg} \text { bid } \\
\text { Rifabutin } 150 \mathrm{mg} \text { bid or } 300 \mathrm{mg} \mathrm{qd}\end{array}$ & 10 & Salvage \\
\hline $\begin{array}{l}\text { Vonoproazan } \\
\text { based therapies }\end{array}$ & $\begin{array}{l}\text { Vonoproazan } 20 \mathrm{mg} \text { bid } \\
\text { Amoxicillin } 750 \mathrm{mg} \text { bid }\end{array}$ & $7-10$ & Approved only in Japan \\
\hline
\end{tabular}

*Nitroimidazole: Metronidazole or tinidazole 
Table 3

Simplified treatment algorithm

\begin{tabular}{|l|l|l|}
\hline & \multicolumn{1}{|c|}{$\begin{array}{c}\text { Prior macrolide use or high resistance } \\
\text { NO }\end{array}$} & \multicolumn{1}{c|}{$\begin{array}{c}\text { Prior macrolide use or high resistance } \\
\text { YES }\end{array}$} \\
\hline Penicillin allergy NO & Any treatment may be used & \\
\hline Recommended first line & Bismuth quadruple & Bismuth quadruple \\
\hline & Concomitant & Levofloxacin triple \\
\hline & Clarithromycin triple & Levofloxacin sequential \\
\hline Other & & Concomitant \\
\hline & Levofloxacin triple & LOAD \\
\hline & Levofloxacin sequential & Hybrid \\
\hline & LOAD & \\
\hline & Hybrid & \\
\hline Penicillin allergy YES & Sequential & Bismuth quadruple \\
\hline & Clarithromycin triple & \\
\hline
\end{tabular}

\section{Who should be tested for cure and how to confirm eradication?}

Test for confirmation of eradication should be offered to any patient treated for HP 4 weeks after the treatment, and can be done by any noninvasive testing (UBT, stool antigen testing) or any of the endoscopy-based testing [20]. Before testing, PPIs should be stopped for 2 weeks and antibiotics or bismuth stopped for 4 weeks to prevent decreased test sensitivity. Gastrointestinal bleeding due to PUD also lowers sensitivity of the test and a negative test result needs to be repeated ideally by urea breath test $[45,46]$.

\section{Strategies to treat refractory $\mathrm{HP}$}

1. Do not use clarithromycin or levofloxacin regimens if the resistance is $>15 \%$ locally.

2. Use bismuth quadruple therapy if not previously used. HP RCTs in Europe and Asia showed an eradication rate of $80 \%$ for a 14 day treatment with bismuth quadruple therapy in patients with a history of treatment failure $[47,48]$

3. In penicillin allergic patients, test for penicillin allergy after first treatment failure since HP rarely develops resistance to amoxicillin.

4. Ensure treatment is for 14 days. if possible.

5. Obtain susceptibility testing for antibiotics

6. Use rifabutin-based therapies or amoxicillin high dose therapy.
7. Vonoproazan-based therapy with amoxicillin is effective with eradication $85-89 \%$. Vonoproazan is only approved in Japan as both first and second line therapies [49].

8. It is important to know the local rate of resistance when considering a quinolone-based regimen.

Strategy to be used in primary care clinics

Test for HP patients with gastric and peptic ulcers, gastric cancer, on long term NSAIDs and on low dose ASA. Test using urea breath test or stool antigen. Treat all patients positive for HP. Treat with twice daily PPI and a combination of antibiotics for 10-14 days. The preferred regimen is bismuth based. Do not use clarithromycin-containing treatments if resistance is $>15 \%$ unless you use 2 other antibiotics in the regimen. Levofloxacinbased therapy should be reserved for treatment failure. Test for penicillin allergy if considering amoxicillin in patients with penicillin allergy history. Know your local antibiotic resistance. Test for cure 4 weeks after antibiotic treatment and 2 weeks after PPI.

\section{CONCLUSION}

Primary care providers are essential in detecting and treating patients with HP. We believe this concise review facilitates understanding of this disease and leads to better patient care.

Helicobacter pylori reprezintă o infecţie frecventă ce poate asocia un număr însemnat de complicaţii gastrointestinale. Deşi majoritatea adulţilor sunt asimptomatici, prevalenţa infecţiei variază în lume şi este mai mare în estul şi sudul Europei. 
Eradicarea infecţiei este necesară pentru a preveni dezvoltarea afectărilor precanceroase cum ar fi atrofia gastrică, metaplasia intestinală şi displazia gastrică. Acest articol prezintă pe cine trebuie să testăm şi cum trebuie să testăm, precum şi indicaţiile terapeutice de primă linie, terapia de salvare, eradicarea infecţiei şi strategia de avut în vedere în cabinetele medicilor de familie.

Correspondence to: Dana Harris, MD, Mayo Clinic, Jacksonville, Florida, 32224.

E-mail: Harris.Dana@mayo.edu

Tel: +1 904-953-9543

Fax: +1 904-953-0655

Conflict of interest disclosure: The authors declare that there are no conflicts of interest.

\section{REFERENCES}

1. PINCOCK S. Nobel Prize winners Robin Warren and Barry Marshall. Lancet. 2005; 366(9495):1429.

2. HOOI JKY., LAI WY., Ng WK., SUEN MMY., UNDERWOOD FE., TANYINGOH D., et al. Global Prevalence of Helicobacter pylori Infection: Systematic Review and Meta-Analysis. Gastroenterology. 2017; 153(2):420-9.

3. PARKINSON AJ., GOLD BD., BULKOW L., WAINWRIGHT RB., SWAMINATHAN B., KHANNA B., et al. High prevalence of Helicobacter pylori in the Alaska native population and association with low serum ferritin levels in young adults. Clin Diagn Lab Immunol. 2000; 7(6):885-8.

4. EVERHART JE., KRUSZON-MORAN D., PEREZ-PEREZ GI., TRALKA TS., MCQUILAN G. Seroprevalence and ethnic differences in Helicobacter pylori infection among adults in the United States. J Infect Dis. 2000; 181(4):1359-63.

5. CARDENAL VM., MULLA ZD., ORTIZ M., GRAHAM DY. Iron deficiency and Helicobacter pylori infection in the United States. Am J Epidemiol. 2006; 163(2):127-34.

6. SCHWARZ S., MORELLI G., KUSECEK B., MANICA A., BALLOUX F., OWEN RJ., et al. Horizontal versus familial transmission of Helicobacter pylori. PLoS Pathog. 2008; 4(10):e1000180.

7. FORD AC., FORMAN D., BAILEY AG., GOODMAN KJ., AXON AT., MOAYYEDI P. Effect of sibling number in the household and birth order on prevalence of Helicobacter pylori: a cross-sectional study. Int J Epidemiol. 2007; 36(6):1327-33.

8. WEYERMANN M., ROTHENBACHER D., BRENNER H. Acquisition of Helicobacter pylori infection in early childhood: independent contributions of infected mothers, fathers, and siblings. Am J Gastroenterol. 2009; 104(1):182-9.

9. JIANG J., CHEN Y., SHI J., SONG C., ZHANG J., WANG K. Population attributable burden of Helicobacter pylori-related gastric cancer, coronary heart disease, and ischemic stroke in China. Eur J Clin Microbiol Infect Dis. 2017; 36(2):199-212.

10. GONI E., FRANCESCHI F. Helicobacter pylori and extragastric diseases. Helicobacter. 2016; 21 Suppl 1:45-8.

11. LIU J., WANG F., SHI S. Helicobacter pylori Infection Increase the Risk of Myocardial Infarction: A Meta-Analysis of 26 Studies Involving more than 20,000 Participants. Helicobacter. 2015; 20(3):176-83.

12. Schistosomes, liver flukes and Helicobacter pylori. IARC Working Group on the Evaluation of Carcinogenic Risks to Humans. Lyon, 7-14 June 1994. IARC Monogr Eval Carcinog Risks Hum. 1994; 61:1-241.

13. KOSUNEN TU., PUKKALA E., SARNA S., SEPPALA K., AROMAA A., KNEKT P., et al. Gastric cancers in Finnish patients after cure of Helicobacter pylori infection: A cohort study. Int J Cancer. 2011; 128(2):433-9.

14. CHEY WD., LEONITIADIS GI., HOWDEN CW., MOSS SF. ACG Clinical Guideline: Treatment of Helicobacter pylori Infection. Am J Gastroenterol. 2017; 112(2):212-39.

15. NAKAMURA S., SUGIYAMA T., MATSUMOTO T., IIJIMA K., ONO S., TAJIKA M., et al. Long-term clinical outcome of gastric MALT lymphoma after eradication of Helicobacter pylori: a multicentre cohort follow-up study of 420 patients in Japan. Gut. 2012; 61(4):507-13.

16. YOON SB., PARK JM., LIM CH., CHO YK., CHOI MG. Effect of Helicobacter pylori eradication on metachronous gastric cancer after endoscopic resection of gastric tumors: a meta-analysis. Helicobacter. 2014; 19(4):243-8.

17. RAGHUNATH AS., HUNGIN AP., WOOFF D., CHILDS S. Systematic review: the effect of Helicobacter pylori and its eradication on gastro-oesophageal reflux disease in patients with duodenal ulcers or reflux oesophagitis. Aliment Pharmacol Ther. 2004; 20(7):733-44.

18. HOWDEN CW., HUNT RH. Guidelines for the management of Helicobacter pylori infection. Ad Hoc Committee on Practice Parameters of the American College of Gastroenterology. Am J Gastroenterol. 1998; 93(12):2330-8.

19. GRAHAM DY., MIFTAHUSSURUR M. Helicobacter pylori urease for diagnosis of Helicobacter pylori infection: A mini review. J Adv Res. 2018; 13:51-7.

20. CHEY WD., WONG BC. American College of Gastroenterology guideline on the management of Helicobacter pylori infection. Am J Gastroenterol. 2007; 102(8):1808-25.

21. TREVISANI L., SARTORI S., GALVANI F., ROSSI MR., RUINA M., CHIAMENTI C., et al. Evaluation of a new enzyme immunoassay for detecting Helicobacter pylori in feces: a prospective pilot study. Am J Gastroenterol. 1999; 94(7):1830-3.

22. VAIRA D., MALFERHEINER P., MEGRAUD F., AXON AT., DELTENRE M., HIRSCHL AM., et al. Diagnosis of Helicobacter pylori infection with a new non-invasive antigen-based assay. HpSA European study group. Lancet. 1999; 354(9172):30-3.

23. MALFERHEINER P., MEGRAUD F., O'MORAIN CA., ATHERTON J., AXON AT., BAZZOLI F., et al. Management of Helicobacter pylori infection - the Maastricht IV/ Florence Consensus Report. Gut. 2012; 61(5):646-64. 
24. MALFERHEINER P., MEGRAUD F., MORAIN CA., GISBERT JP., KUIPERS EJ., AXON AT., et al. Management of Helicobacter pylori infection - the Maastricht V/Florence Consensus Report. Gut. 2017; 66(1):6.

25. YANEZ P., LA GARZA AM., PEREZ-PEREZ G., CABRERA L., MUNOZ O., TORRES J. Comparison of invasive and noninvasive methods for the diagnosis and evaluation of eradication of Helicobacter pylori infection in children. Arch Med Res. 2000; 31(4):415-21.

26. BRANDI G., BIAVATI B., CALABRESE C., GRANATA M., NANNETTI A., MATTARELLI P., et al. Urease-positive bacteria other than Helicobacter pylori in human gastric juice and mucosa. Am J Gastroenterol. 2006; 101(8):1756-61.

27. WRIGHT CL., KELLY JK. The use of routine special stains for upper gastrointestinal biopsies. Am J Surg Pathol. 2006; 30(3):357-61.

28. GENTA RM., GRAHAM DY. Comparison of biopsy sites for the histopathologic diagnosis of Helicobacter pylori: a topographic study of H. pylori density and distribution. Gastrointest Endosc. 1994; 40(3):342-5.

29. TAYLOR DE., GE Z., PURYCH D., LO T., HIRATSUKA K. Cloning and sequence analysis of two copies of a $23 S$ rRNA gene from Helicobacter pylori and association of clarithromycin resistance with $23 S$ rRNA mutations. Antimicrob Agents Chemother. 1997; 41(12):2621-8.

30. HIRSCHL AM., MAKRISTATHIS A. Methods to detect Helicobacter pylori: from culture to molecular biology. Helicobacter. 2007; 12 Suppl 2:6-11.

31. YUAN Y., FORD AC., KHAN KJ., GISBERT JP., FORMAN D., LEONTIADIS GI., et al. Optimum duration of regimens for Helicobacter pylori eradication. Cochrane Database Syst Rev. 2013; (12):Cd008337.

32. FALLONE CA., CHIBA N., VAN ZANTEN SV., FISCHBACH L., GISBERT JP., HUNT RH., et al. The Toronto Consensus for the Treatment of Helicobacter pylori Infection in Adults. Gastroenterology. 2016; 151(1):51-69.e14.

33. LI BZ., THREAPLETON DE., WANG JY., XU JM., YUAN JQ., ZHANG C., et al. Comparative effectiveness and tolerance of treatments for Helicobacter pylori: systematic review and network meta-analysis. Bmj. 2015; 351:h4052.

34. NISTA EC., CANDELLI M., CREMONINI F., CAZZATO IA., DI CAROA S., GABRIELLI M., et al. Levofloxacin-based triple therapy vs. quadruple therapy in second-line Helicobacter pylori treatment: a randomized trial. Aliment Pharmacol Ther. 2003; 18(6):627-33.

35. BILARDI C., DULBECCO P., ZENTILIN P., REGLIONI S., IIRITANO E., PARODI A., et al. A 10-day levofloxacin-based therapy in patients with resistant Helicobacter pylori infection: a controlled trial. Clin Gastroenterol Hepatol. 2004; 2(11):997-1002.

36. SAAD RJ., SCHOENFELD P., KIM HM., CHEY WD. Levofloxacin-based triple therapy versus bismuth-based quadruple therapy for persistent Helicobacter pylori infection: a meta-analysis. Am J Gastroenterol. 2006; 101(3):488-96.

37. ERCIN CN., UYGUN A., TOROS AB., KANTARCIOGLU M., KILCILER G., POLAT Z., et al. Comparison of 7- and 14-day first-line therapies including levofloxacin in patients with Helicobacter pylori positive non-ulcer dyspepsia. Turk J Gastroenterol. 2010; 21(1):12-6.

38. BASU PP., RAYAPUDI K., PACANA T., SHAH NJ., KRISHNASWAMY N., FLYNN M. A randomized study comparing levofloxacin, omeprazole, nitazoxanide, and doxycycline versus triple therapy for the eradication of Helicobacter pylori. Am $\mathrm{J}$ Gastroenterol. 2011; 106(11):1970-5.

39. KALE-PRADHAN PB., MIHAESCU A., WILHELM SM. Fluoroquinolone Sequential Therapy for Helicobacter pylori: A Metaanalysis. Pharmacotherapy. 2015; 35(8):719-30.

40. GREENBERG ER., ANDERSON GL., MORGAN DR., TORRES J., CHEY WD., BRAVO LE., et al. 14-day triple, 5-day concomitant, and 10-day sequential therapies for Helicobacter pylori infection in seven Latin American sites: a randomised trial. Lancet. 2011; 378(9790):507-14.

41. MIEHLKE S., HHANSKY K., SCHNEIDER-BRACHERT W., KIRSCH C., MORGANER A., MADISCH A., et al. Randomized trial of rifabutin-based triple therapy and high-dose dual therapy for rescue treatment of Helicobacter pylori resistant to both metronidazole and clarithromycin. Aliment Pharmacol Ther. 2006; 24(2):395-403.

42. LABENZ J. Current role of acid suppressants in Helicobacter pylori eradication therapy. Best Pract Res Clin Gastroenterol. 2001; 15(3):413-31.

43. SHIOTA S., REDDY R., ALSARRAJ A., EL-SSERAG HB., GRAHAM DY. Antibiotic Resistance of Helicobacter pylori Among Male United States Veterans. Clin Gastroenterol Hepatol. 2015; 13(9):1616-24.

44. PERRI F., FESTA V., CLEMENTE R., VILLANI MR., QUITADAMO M., CARUSO N., et al. Randomized study of two "rescue" therapies for Helicobacter pylori-infected patients after failure of standard triple therapies. Am J Gastroenterol. 2001; 96(1):58-62.

45. GISBERT JP., ABRAIRA V. Accuracy of Helicobacter pylori diagnostic tests in patients with bleeding peptic ulcer: a systematic review and meta-analysis. Am J Gastroenterol. 2006; 101(4):848-63.

46. GISBERT JP., ESTEBAN C., JIMENEZ I., MORENO-OTERO R. 13C-urea breath test during hospitalization for the diagnosis of Helicobacter pylori infection in peptic ulcer bleeding. Helicobacter. 2007; 12(3):231-7.

47. MIEHLKE S., KIRSCH C., SCHNEIDER-BRACHERT W., HHAFERLAND C., NEUMEYER M., BASTLEIN E., et al. A prospective, randomized study of quadruple therapy and high-dose dual therapy for treatment of Helicobacter pylori resistant to both metronidazole and clarithromycin. Helicobacter. 2003; 8(4):310-9.

48. CAO Z., CCHEN Q., ZHANG W., LIANG X., LIAO J., LIU W., et al. Fourteen-day optimized levofloxacin-based therapy versus classical quadruple therapy for Helicobacter pylori treatment failures: a randomized clinical trial. Scand J Gastroenterol. 2015; 50(10):1185-90.

49. DONG SQ., SINGH TP., WEI X., YAO H., WANG HL. Review: A Japanese population-based meta-analysis of vonoprazan versus PPI for Helicobacter pylori eradication therapy: Is superiority an illusion? Helicobacter. 2017; 22(6):e12438.

Received $2^{\text {nd }}$ November 2020 